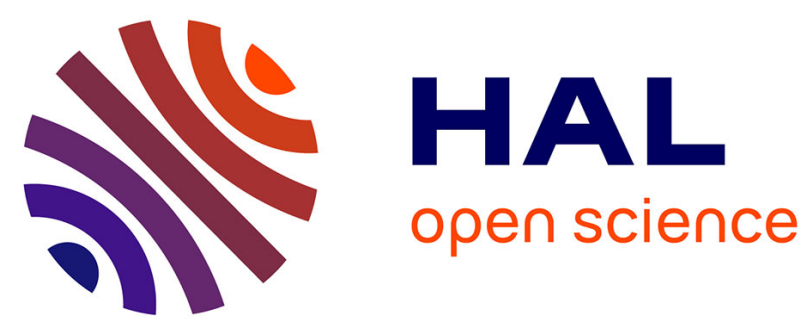

\title{
Update on Strategies to Reduce Infectious Complications After Prostate Biopsy
}

\author{
Adrian Pilatz, Rajan Veeratterapillay, Bela Köves, Tommaso Cai, Riccardo \\ Bartoletti, Florian Wagenlehner, Franck Bruyère, Suzanne Geerlings, Gernot \\ Bonkat, Benjamin Pradere
}

\section{To cite this version:}

Adrian Pilatz, Rajan Veeratterapillay, Bela Köves, Tommaso Cai, Riccardo Bartoletti, et al.. Update on Strategies to Reduce Infectious Complications After Prostate Biopsy. European Urology Focus, 2019, 5, pp.20 - 28. 10.1016/j.euf.2018.11.009 . hal-03484497

\section{HAL Id: hal-03484497 \\ https://hal.science/hal-03484497}

Submitted on 20 Dec 2021

HAL is a multi-disciplinary open access archive for the deposit and dissemination of scientific research documents, whether they are published or not. The documents may come from teaching and research institutions in France or abroad, or from public or private research centers.
L'archive ouverte pluridisciplinaire HAL, est destinée au dépôt et à la diffusion de documents scientifiques de niveau recherche, publiés ou non, émanant des établissements d'enseignement et de recherche français ou étrangers, des laboratoires publics ou privés.

\section{(ㅇ)(1) $\$$}

Distributed under a Creative Commons Attribution - NonCommerciall 4.0 International 


\title{
Update on Strategies to Reduce Infectious Complications After Prostate Biopsy
}

Adrian Pilatz ${ }^{\text {a }}$, Rajan Veeratterapillay ${ }^{\text {b }}$, Bela Köves ${ }^{\text {c }}$, Tommaso Cai ${ }^{\text {d }}$, Riccardo Bartoletti ${ }^{\text {e }}$, Florian Wagenlehner ${ }^{\mathrm{a}}$, Franck Bruyère ${ }^{\mathrm{f}}$, Suzanne Geerlings ${ }^{\mathrm{g}}$, Gernot Bonkat ${ }^{\mathrm{h}}$, Benjamin Pradère $\mathrm{f}, *$

${ }^{a}$ Department of Urology, Paediatric Urology and Andrology, Justus-Liebig-University,

Giessen, Germany

${ }^{\mathrm{b}}$ Department of Urology, Newcastle University, Newcastle, UK

${ }^{\mathrm{c}}$ South-Pest Teaching Hospital, Department of Urology, Budapest, Hungary

${ }^{\mathrm{d}}$ Santa Chiara Regional Hospital, Department of Urology, Trento, Italy

${ }^{\mathrm{e}}$ Department of Experimental and Clinical Medicine, University of Florence, Florence, Italy

${ }^{\mathrm{f}}$ Academic Department of Urology, CHRU Tours, François Rabelais University, Tours, France

g Division of Infectious Diseases, Amsterdam University Medical Centre, Amsterdam, The Netherlands

${ }^{\mathrm{h}}$ alta uro AG, Merian Iselin Klinik, Center of Biomechanics \& Calorimetry (COB), University of Basel, Basel, Switzerland

* Corresponding author. CHU Tours, Urology, 2 Boulevard Tonnelé, Tours, 37044, France. Tel. +33 661404418; Fax: +33 661404418.

E-mail address: benjaminpradere@gmail.com; medoc31@ hotmail.fr (B. Pradère).

\begin{abstract}
Context: Prostate biopsy is one of the most performed procedures in urology. As a diagnostic procedure it should be of low risk. However, morbidity following prostate biopsy is common due to infectious complications.
\end{abstract}


Objective: To describe how to reduce infectious complications following prostate biopsy. We report on antibiotic and technical interventions to reduce infectious complications.

Evidence acquisition: The data presented are based on a narrative review. Search in PubMed and Medline was performed until May 2018 with a focus on randomised controlled trials and meta-analyses. Articles were reviewed for data on symptomatic infections, hospitalisation, and adverse events.

Evidence synthesis: Antibiotic prophylaxis is the standard of care. However, the duration of antibiotic preemptive treatment is still under debate. The use of augmented antibiotic prophylaxis as well as targeted antibiotic prophylaxis might be of potential value, but evidence is currently limited. Moreover, no antibiotic class was shown to be clearly superior to another. The evaluation of the technical aspects during prostate biopsy reveals that rectal preparation with povidone-iodine is clearly effective to reduce infectious complications. Transperineal biopsy has a potential benefit to reduce infectious complications, but powerful randomised controlled studies are missing. Finally, the number of biopsy cores, the application of periprostatic nerve block, or the use of a cleansing enema has no impact on prostate biopsy in terms of infectious complications.

Conclusions: The available data only suggest that rectal preparation with povidone-iodine as well as antibiotic prophylaxis is of significant advantage to reduce infectious complications following prostate biopsy. The augmented and targeted antibiotic prophylaxis shows some potential, but need further validation.

Patient summary: In this review we evaluate the best management strategy to prevent infectious complications following prostate biopsy. We show that antibiotic prophylaxis is essential for prostate biopsy and that rectal preparation with povidone-iodine is mandatory. 
Keywords: Antibiotic prophylaxis; Infectious complications; Prostate biopsy; Prostate cancer; Urosepsis

\section{Introduction}

Biopsy of the prostate gland is frequently needed among older (generally $>50 \mathrm{yr}$ ) men to obtain tissue samples that can be examined histologically to identify prostate cancer. Need for biopsy is suggested by an abnormal feeling prostate on digital rectal examination, a high reading of the serum tumour marker prostate-specific antigen (PSA), or changes in appearance of the prostate on imaging. It is estimated that more than 1 million men over $65 \mathrm{yr}$ had a prostate biopsy under the Medicare program in the USA in 2003 with an annual prevalence of about 1600/100 000 men at risk [1]. The National Health Service in the UK recorded 49495 men as having had a prostate biopsy in 2015, giving a biopsy prevalence of 500/100 000 men at risk/year [2]. Most of prostate biopsies are transrectal ultrasound guided [3]. Thus, biopsy needles can be accurately placed in the prostate under local anaesthesia with ultrasound image guidance and a systematic sequence of tissue samples taken for examination [4]. Each biopsy core requires a separate entry and passage of the needle and generally a single needle is repeatedly used to obtain a set of biopsies from each individual. Passing a needle into the prostate from the bowel risks introducing bacteria into the tissue layers, urinary system, or bloodstream causing infection ranging in severity from mild prostate inflammation to life-threatening sepsis requiring hospitalisation and intensive care. However, the risk varies between cohorts and according to differing definitions of infection. While complications of infections were only rarely evident in the past, recent evidence indicates increasing rates of postbiopsy infections. In this line, one Canadian study reported an increase from $1 \%$ in 1996 to $4.1 \%$ in 2005 and a mortality in 1 out of 1000 men following prostate 
biopsy [5]. A recent well-controlled study found a 7\% rate of microbiologically proven infection [6].

Two major strategies could reduce risk of infection after biopsies: (1) administration of antimicrobial drugs, and (2) technical modifications. The most frequently used strategy is administration of an antibiotic prophylaxis. The rationale is that if a sufficient concentration of antibiotic is present in the prostate during the biopsy, survival of bacteria implanted by the biopsy needle will be limited and clinical infection will not result. Other antimicrobial interventions have included washing the rectal wall with antiseptic such as povidone-iodine prior to biopsy to reduce bacterial contamination of the needle entry point. Technical modifications to the biopsy procedure such as using a clean needle for each tissue sample, using smaller gauge needles, minimising the number of tissue samples obtained, accessing the prostate through the perineal skin rather than rectum, and applying enemas to clear the rectum have been proposed to reduce infections.

This narrative review follows the aim to highlight the most promising antimicrobial and technical strategies to reduce infectious complications in patients undergoing prostate biopsy.

\section{Evidence acquisition}

This narrative review summarises recent evidence on how to reduce infectious complications following prostate biopsy. The systematic reviews generally focus on specific interventions (eg, specific antibiotics, rectal preparation, or targeted antibiotic prophylaxis). Here, we report on all possible interventions also referencing recent systematic reviews. We searched for all different interventions that were looking to prevent infectious complications following 
prostate biopsy. A focused database search was performed in PubMed and Medline without any language or year restrictions with a focus on randomised controlled trials (RCTs) and meta-analyses using the search terms "prostate biopsy" and "infection/infectious complications." In addition, the reference lists of the identified studies were checked. There was no restriction regarding the cohort size of these studies. Non-English articles were evaluated in the corresponding languages, and if necessary, a translation in English was performed by a native urologist speaker. The aim of this narrative review is focused on selective issues being of relevance for the urologist performing prostate biopsy. In the context of a narrative review, we did not perform a risk of bias assessment.

\section{Evidence synthesis}

\subsection{Antimicrobial regimens}

\subsubsection{Antibiotic therapy to decrease PSA values}

Although PSA is specific for prostate tissue, it is not only increased in prostate cancer, but also in urogenital tract infections [7]. Various studies investigated the impact of antibiotic therapy to normalise PSA values and thus possibly to reduce the number of unnecessary prostate biopsies. A meta-analysis including six RCTs involving 656 patients showed that PSA levels neither did not decrease significantly [mean difference $=0.15,95 \%$ confidence interval $(\mathrm{CI}):-0.50$ to $0.81, p=0.6$ ] nor did the cancer rates differ significantly [relative risk $(\mathrm{RR})=0.85,95 \% \mathrm{CI}: 0.48-1.50, p=0.57]$ [8]. In summary, a several weeks lasting empiric antibiotic therapy-also in view of developing antibiotic resistance-cannot be recommended. 


\subsubsection{Antibiotic prophylaxis}

Antibiotic prophylaxis to reduce infectious complications was evaluated for the first time in a randomised study published in 1979 [9]. Many more studies followed and were comprehensively analysed in a Cochrane review 2011 [10]. For all investigated parameters [bacteriuria, bacteraemia, urinary tract infection (UTI), fever, and hospitalisation] the antibiotic prophylaxis was superior compared with the control/placebo groups (in all cases $p<$ 0.05). In 2015 another updated systematic review and meta-analysis was published including nine trials analysing antibiotics versus placebo/no treatment. Comparably, the authors could show the clinical benefit of antibiotic prophylaxis compared with control/no prophylaxis regarding the primary end points bacteriuria, bacteraemia, fever, UTI, and hospitalisation (in all cases $p<0.05)$ [11]. Interestingly, the rate of adverse events due to antibiotic prophylaxis was not increased in the antibiotic intervention group $(p=0.63)$ [10]. Thus, antibiotic prophylaxis is currently the gold standard worldwide [3].

\subsubsection{Duration of antibiotic prophylaxis}

The duration of antibiotic prophylaxis is a matter of debate. The currently available RCTs include single shots, 1-, 3-, 5-, and 7-d regimes. The Cochrane analysis of 2011 compared a 3$\mathrm{d}$ regimen with a single-shot/1 d prophylaxis and in all analysed end points no significant differences were detected (for all $p>0.05$ ); only postoperative bacteriuria was reduced in the 3-d intervention $(p=0.01)$ [10]. However, the Cochrane analysis from 2011 excluded studies with patients being at risk for infective complications (eg, indwelling catheters, diabetes) and mixed up a single-shot prophylaxis without full 24-h duration of action and full 1-d regimens. In an updated meta-analysis from 2015, again, no substantial differences between long-course versus short-course treatment were detected regarding the clinical outcomes fever, UTI, and 
hospitalisation (in all cases $p>0.05$ ) [11]. To summarise, future meta-analyses will have to include studies with patients being at risk for infectious complications to represent the real clinical situation.

\subsubsection{Augmented antibiotic prophylaxis}

Combination of multiple antibiotics was proposed to overcome increased infectious complications caused by antibiotic resistance. Most studies report infectious complications in a retrospective arm and compare the data with a prospective arm recorded after the introduction of a combination therapy [12].

A meta-analysis published in 2016 identified three RCTs with 659 patients and five case-control studies with 3404 patients on this issue [12]. Similar to the Cochrane review of Zani et al [10], patients with heart disease, prosthesis, prebiopsy bacteriuria, and indwelling catheters were excluded. The authors evaluated bacteriuria, bacteraemia, fever, UTI, hospitalisation, and drug-resistant bacteria isolated in urine and blood. All seven end points significantly favoured the augmented antibiotic use (in all cases $p<0.05$ ). The authors also concluded that the addition of an antibiotic agent to the basic antibiotic prophylaxis can contribute to the reduction in severe infection and drug resistance. They point out that this might be beneficial for high-risk patients, although exactly those were excluded in these studies. In addition, it has to be considered that the case-control studies usually compare data from a retrospective cohort (with usually high infection rates) with a prospective arm recorded after the introduction of an intervention using a combination therapy. Thus, a significant bias is present. 
The augmented prophylaxis can lead to questionable dimensions in terms of antimicrobial stewardship: In the most recent study performed in Iran, the authors randomised 450 patients to a combination of four different antimicrobials (ceftriaxone plus amikacin plus ciprofloxacin plus metronidazole) or the standard prophylaxis (ciprofloxacin plus metronidazole) [13]. The incidence of infectious complications in the intervention group was reported to be significantly lower than that in the control group ( $4.6 \%$ vs $0.9 \%, p=0.017)$. However, the long-term complications regarding the development of antimicrobial resistance must be considered.

\subsubsection{Choice of antibiotic class}

Several studies investigated the most suitable antibiotic for prophylaxis in men undergoing prostate biopsy. Because of their valuable pharmacokinetic properties in prostatic tissue, fluoroquinolones have been widely evaluated. However, in the analysis of available RCTs no antibiotic class was shown to be clearly superior. This was also shown in the Cochrane review by Zani et al [10]. Specifically, the fluoroquinolones have been in discussion in recent years because of increasing fluoroquinolone resistance in the faecal flora. Currently, fosfomycin is in focus as a good alternative. However, from the three available RCTs, only one RCT showed a significant reduction of infectious complications compared with standard prophylaxis with fluoroquinolones [14-16] (Table 1). Nevertheless, a recent meta-analysis that included those three RCTs and two retrospective cohorts reported significantly lower infectious complications in the fosfomycin cohort compared with the fluoroquinolone-based prophylaxis $(\mathrm{RR}=0.20,95 \% \mathrm{CI}=0.58-5.23, p=0.00001)$ [17], but the local resistance percentages of the most common causative microorganisms have to be taken into account to make an optimal choice. Nevertheless, these results could encourage the use of fosfomycin in 
case of fluoroquinolones contraindications, or in patients treated with quinolones in the last 6 mo. In patients with renal failure (glomerular filtration rate $<50 \mathrm{ml} / \mathrm{min}$ ) a $50-75 \%$ dose reduction should be done. In cases of high risk of infections with renal failure $<10 \%$ quinolones should not be used.

\subsubsection{Targeted antibiotic prophylaxis}

Considering the increase in fluoroquinolone resistance in faecal isolates, the use of a rectal swab with subsequent bacterial culture for prebiopsy screening could offer individual targeted antimicrobial therapy. Recently, a systematic review was performed on this issue and included 15 studies (only one RCT) with 12320 patients [18]. Targeted antibiotic prophylaxis resulted in significantly less infectious complications $(0.81 \%)$ compared with standard antibiotic prophylaxis (3.40\%). This translates to an estimated number needed to treat of 39 with targeted antibiotic prophylaxis compared with standard antibiotic prophylaxis to prevent one postbiopsy infection [18]. The authors further concluded that fluoroquinolone resistance drives the higher rates of infectious complications in the standard antibiotic prophylaxis group [18]. To date, a total of three RCTs have been published involving 1337 patients [19-21] (Table 2).

While in two studies infectious complications occurred only in the standard prophylaxis group [20,21], the third study showed an equal distribution of infectious complications [19]. Of note, the later study demonstrated an unusually high rate of infectious complications with a sepsis rate of 5.2\% among all groups [19]. To give a final recommendation, a meta-analysis of the available RCTs is mandatory. 


\subsection{Technical aspects}

Various technical aspects of the prostate biopsy might have an impact on the infection rate. Hence, we report on different technical aspects including number of biopsy cores, needle size, needle disinfection, use of periprostatic nerve block, biopsy route (transrectal vs transperineal), use of disposable needle, rectal preparation with enema, and rectal disinfection with povidone-iodine.

\subsubsection{Number of biopsy cores}

When prostate biopsy was introduced only a few biopsy cores were taken under digital transrectal guidance [22]. With the broader availability of transrectal ultrasound, the technique was optimised and the number of biopsy cores increased for diagnostic reasons. However, only a few studies reported infectious complications while focusing on diagnostic accuracy. So far, no published meta-analysis is available that analyses this issue. However, the available RCTs show comparable infection rates [23-29] (Table 3). This is fully in agreement with the latest evaluation of the Global Prevalence of Infections in Urology study, showing that there is no increase of infectious complications with an increase in the number of biopsy cores [3].

\subsubsection{Periprostatic nerve block as local anaesthesia}

To reduce biopsy-associated pain, periprostatic nerve block is widely used. Several metaanalyses demonstrated a clear advantage compared with topic application of local anaesthesia. Interestingly, a recent meta-analysis reported on the effectiveness of periprostatic nerve block and also investigated adverse events, including infectious complications. However, of the 32 
RCTs, only seven studies with a total of 1026 patients were available for comparison. Here, no significant differences in complications were evident compared with control or topical anaesthesia (in all cases $p>0.05$ ). However, no detailed tabulation on complications (eg, bleeding, sepsis, anaphylaxia) was provided [30]. Thus, the risk of increased postbiopsy infections by the additional transrectal passage and spread of local anaesthesia into the periprostatic tissue has to be systematically investigated in the future.

\subsubsection{Route of biopsy (transrectal vs transperineal)}

While the transrectal approach is always associated with a passage of the rectum, the transperineal approach offers the possibility to avoid the rectal flora. Thus, theoretically the risk of infectious complications should be reduced when using the transperineal biopsy technique. To date, only three RCTs involving 646 men have compared transrectal and transperineal routes of biopsy (Table 4). Overall, two men $(0.4 \%)$ experienced infectious complications after transperineal biopsy, compared with five (1.1\%) after transrectal biopsy. However, the studies were heterogeneous in design, did not state how infectious outcomes were assessed, and used differing antimicrobial prophylaxis between arms [31-33].

A systematic review and meta-analysis based on those three RCTs and four more case-control studies could not demonstrate an advantage of transperineal biopsies in terms of infections (no $p$ value reported) [34].

Recently, a systematic review evaluated 165 articles comprising 162577 patients reporting on infectious complications following prostate biopsy. The analysis showed a higher rate of hospitalisation $(1.1 \%$ vs $0.9 \%)$ and sepsis $(0.8 \%$ vs $0.1 \%)$ in the transrectal approach 
compared with the transperineal route. Of note, the included studies were largely heterogenous with clear regional variations in complications rates [35].

\subsubsection{Rectal preparation}

Different regimens have been proposed. The most common one is using a rectal povidoneiodine preparation before biopsy [22]. This was reported for the first time in 1981 to reduce infectious complications. Meta-analysis of six trials including 1373 men showed that use of a rectal povidone-iodine preparation before biopsy in addition to antimicrobial prophylaxis resulted in a lower rate of infectious complications $(\mathrm{RR}=0.58,95 \% \mathrm{CI}: 0.43-0.76, p=$ 0.0001) [22,36-40]. A further single RCT showed a significant benefit for performing povidone-iodine preparation before biopsy compared with performing it after biopsy [41].

Another strategy to remove stool before biopsy is to use an enema. Here, two RCTs including 209 men demonstrated a comparable number of infectious complications following prostate biopsy $[42,43]$. Instead of using the standard lubricant an antimicrobial lubricant was evaluated in another RCT showing a reduction of the bacterial counts in the rectum without a benefit of postbiopsy infections [44].

Finally, a single RCT showed no evidence of benefit for perineal skin disinfection [45]. Hence, the rectal preparation with povidone-iodine is currently the only technical intervention to decrease infectious complications following prostate biopsy.

\subsubsection{Other technical interventions}


The transrectal biopsy is usually performed with a reusable needle guide. Thus, two RCTs with 253 participants evaluated disposable needle guides and reported nine infectious complications compared to 22 with reusable biopsy needle guides. However, the difference was not significant (in both studies $p>0.05$ ) [46,47].

Two other RCTs including 138 men compared the needle size ( $16 \mathrm{G}$ vs $18 \mathrm{G}$ ) in terms of diagnostic accuracy and complications. In both studies, infectious complications did never occur $[48,49]$. Finally, a single RCT found no evidence that disinfection of a single-patientuse needle between cores resulted in fewer infectious complications [50].

\section{Conclusions}

Although various interventions have been published, a comprehensive analysis of the available data only suggests that rectal preparation with povidone-iodine as well as antibiotic prophylaxis is of significant advantage to reduce infectious complications following prostate biopsy. The augmented and targeted antibiotic prophylaxis shows some potential, but need further validation.

Author contributions: Benjamin Pradère had full access to all the data in the study and takes responsibility for the integrity of the data and the accuracy of the data analysis.

Study concept and design: Pilatz, Pradère, Wagenlehner, Veeratterapillay, Köves, Cai.

Acquisition of data: Pilatz, Pradère, Veeratterapillay.

Analysis and interpretation of data: Pilatz, Pradère, Veeratterapillay. 
Drafting of the manuscript: Pilatz, Pradère, Geerlings, Wagenlehner.

Critical revision of the manuscript for important intellectual content: Köves, Cai, Bartoletti, Bruyère, Bonkat, Geerlings.

Statistical analysis: Pilatz.

Obtaining funding: None.

Administrative, technical, or material support: None.

Supervision: Bonkat, Wagenlehner, Geerlings, Bruyère, Bartoletti.

Other: None.

Financial disclosures: Benjamin Pradère certifies that all conflicts of interest, including specific financial interests and relationships and affiliations relevant to the subject matter or materials discussed in the manuscript (eg, employment/affiliation, grants or funding, consultancies, honoraria, stock ownership or options, expert testimony, royalties, or patents filed, received, or pending), are the following: None.

Funding/Support and role of the sponsor: None.

\section{References}

1. Loeb S, et al. Complications after prostate biopsy: data from SEER-Medicare. J Urol 2011;186:1830-4.

2. Health, U.D.o., 2015.

3. Wagenlehner FME, et al. Infective complications after prostate biopsy: outcome of the Global Prevalence Study of Infections in Urology (GPIU) 2010 and 2011. A prospective multinational multicentre prostate biopsy study. Eur Urol 2013;63:521-7. 
4. Hodge KK, McNeal JE, Stamey TA. Ultrasound guided transrectal core biopsies of the palpably abnormal prostate. J Urol 1989;142:66-70.

5. Nam RK, et al. Increasing hospital admission rates for urological complications after transrectal ultrasound guided prostate biopsy. J Urol 2010;183:963-8.

6. Ahmed HU, et al. Diagnostic accuracy of multi-parametric MRI and TRUS biopsy in prostate cancer (PROMIS): a paired validating confirmatory study. Lancet 2017;389:815-22.

7. Pilatz A, et al. Acute epididymitis revisited: impact of molecular diagnostics on etiology and contemporary guideline recommendations. Eur Urol 2015;68:428-35.

8. Yang L, et al. Antibiotics may not decrease prostate-specific antigen levels or prevent unnecessary prostate biopsy in patients with moderately increased prostate-specific antigen levels: a meta-analysis. Urol Oncol 2015;33:201.e17-e24.

9. Ruebush ITK, McConville JH, Calia FM. A double-blind study of trimethoprimsulfamethoxazole prophylaxis in patients having transrectal needle biopsy of the prostate. J Urol 1979;122:492-4.

10. Zani EL, Clark OA, Rodrigues Netto N Jr. Antibiotic prophylaxis for transrectal prostate biopsy. Cochrane Database Syst Rev 2011:CD006576.

11. Yang L, et al. Prophylactic antibiotics in prostate biopsy: a meta-analysis based on randomized controlled trials. Surg Infect (Larchmt) 2015;16:733-47.

12. Yang L, et al. The augmented prophylactic antibiotic could be more efficacious in patients undergoing transrectal prostate biopsy: a systematic review and meta-analysis. Int Urol Nephrol 2016;48:1197-1207.

13. Izadpanahi MH, et al. Addition of ceftriaxone and amikacin to a ciprofloxacin plus metronidazole regimen for preventing infectious complications of transrectal ultrasound-guided prostate biopsy: a randomized controlled trial. Adv Urol 2017;2017:4635386. 
14. Fahmy AM, et al. Fosfomycin antimicrobial prophylaxis for transrectal ultrasoundguided biopsy of the prostate: a prospective randomised study. Arab J Urol 2016; $14: 228-33$.

15. Lista F, et al. Efficacy and safety of fosfomycin-trometamol in the prophylaxis for transrectal prostate biopsy. Prospective randomized comparison with ciprofloxacin. Actas Urol Esp 2014;38:391-6.

16. Sen V, et al. The use of prophylactic single-dose fosfomycin in patients who undergo transrectal ultrasound-guided prostate biopsy: a prospective, randomized, and controlled clinical study. Can Urol Assoc J 2015;9:E863-E7.

17. Noreikaite J, et al. Fosfomycin vs. quinolone-based antibiotic prophylaxis for transrectal ultrasound-guided biopsy of the prostate: a systematic review and metaanalysis. Prostate Cancer Prostatic Dis 2018;21:153-60.

18. Scott $\mathrm{S}$, et al. The effectiveness of targeted relative to empiric prophylaxis on infectious complications after transrectal ultrasound-guided prostate biopsy: a metaanalysis. World J Urol 2018;36:1007-1017

19. Elshal AM, Atwa AM, El-Nahas AR, et al. Chemoprophylaxis during transrectal prostate needle biopsy: critical analysis through randomized clinical trial. World $\mathbf{J}$ Urol. In press. http://dx.doi.org/10.1007/s00345-018-2319-2

20. Fahmy A, et al. Optimizing prophylactic antibiotic regimen in patients admitted for transrectal ultrasound-guided prostate biopsies: a prospective randomized study. Prostate Int 2016;4:113-7.

21. Ozgur A, et al. Prevalence of antibiotic resistance in fecal flora before transrectal ultrasound-guided prostate biopsy and the clinical impact of targeted antibiotic prophylaxis. Arch Esp Urol 2017;70:852-8.

22. Brown RW, et al. Bacteremia and bacteriuria after transrectal prostatic biopsy. Urology 1981;18:145-8. 
23. Emiliozzi $\mathrm{P}$, et al. The incidence of prostate cancer in men with prostate specific antigen greater than $4.0 \mathrm{ng} / \mathrm{ml}$ : a randomized study of 6 versus 12 core transperineal prostate biopsy. J Urol 2004;171:197-9.

24. Irani J, et al. Is an extended 20-core prostate biopsy protocol more efficient than the standard 12-core? A randomized multicenter trial. J Urol 2013;190:77-83.

25. Mariappan $\mathrm{P}$, et al. Increasing prostate biopsy cores based on volume vs the sextant biopsy: a prospective randomized controlled clinical study on cancer detection rates and morbidity. BJU Int 2004;94:307-10.

26. Naughton CK, et al. Pain and morbidity of transrectal ultrasound guided prostate biopsy: a prospective randomized trial of 6 versus 12 cores. J Urol 2000;163:168-71.

27. Paul R, et al. Morbidity of prostatic biopsy for different biopsy strategies: is there a relation to core number and sampling region? Eur Urol 2004;45:450-5.

28. Rodríguez-Covarrubias F, et al. Extended sampling at first biopsy improves cancer detection rate: results of a prospective, randomized trial comparing 12 versus 18 -core prostate biopsy. J Urol 2011;185:2132-6

29. Sur RL, et al. A prospective randomized comparison of extensive prostate biopsy to standard biopsy with assessment of diagnostic yield, biopsy pain and morbidity. Prostate Cancer Prostatic Dis 2004:7:126-31.

30. Yang Y, et al. The efficiency and safety of intrarectal topical anesthesia for transrectal ultrasound-guided prostate biopsy: a systematic review and meta-analysis. Urol Int 2017;99:373-83.

31. Chae Y, et al. The comparison between transperineal and transrectal ultrasoundguided prostate needle biopsy. Korean J Urol 2009;50:119-24.

32. Hara R, et al. Optimal approach for prostate cancer detection as initial biopsy: prospective randomized study comparing transperineal versus transrectal systematic 12-core biopsy. Urology 2008;71:191-5. 
33. Takenaka A, et al. A prospective randomized comparison of diagnostic efficacy between transperineal and transrectal 12-core prostate biopsy. Prostate Cancer Prostatic Dis 2008:11:134-8.

34. Shen PF, et al. The results of transperineal versus transrectal prostate biopsy: a systematic review and meta-analysis. Asian J Androl 2012;14:310-5.

35. Bennett HY, et al. The global burden of major infectious complications following prostate biopsy. Epidemiol Infect 2016;144:1784-91.

36. Abughosh Z, et al. A prospective randomized trial of povidone-iodine prophylactic cleansing of the rectum before transrectal ultrasound guided prostate biopsy. J Urol 2013;189:1326-31

37. Ghafoori $\mathrm{M}$, et al. Decrease in infection rate following use of povidone-iodine during transrectal ultrasound guided biopsy of the prostate: a double blind randomized clinical trial. Iran J Radiol 2012;9:67-70.

38. Kanjanawongdeengam $\mathrm{P}$, et al. Reduction in bacteremia rates after rectum sterilization before transrectal, ultrasound-guided prostate biopsy: a randomized controlled trial. J Med Assoc Thai 2009;92:1621-6.

39. Sharpe JR, et al. Urinary tract infection after transrectal needle biopsy of the prostate. J Urol 1982;127:255-6.

40. Melekos MD. Efficacy of prophylactic antimicrobial regimens in preventing infectious complications after transrectal biopsy of the prostate. Int Urol Nephrol 1990;22:25762.

41. $\mathrm{Yu} \mathrm{L}, \mathrm{Ma} \mathrm{L}, \mathrm{Yu} \mathrm{H}$. Impact of insertion timing of iodophor cotton ball on the control of infection complications after transrectal ultrasound guided prostate biopsy. Natl Med J China 2014;94:609-11.

42. Lindert KA, Kabalin JN, Terris MK. Bacteremia and bacteriuria after transrectal ultrasound guided prostate biopsy. J Urol 2000;164:76-80. 
43. Tekdogan $\mathrm{U}$, et al. The efficiency of prophylactic antibiotic treatment in patients without risk factor who underwent transrectal. Türk Üroloji Derneği 2006;32:261-7.

44. Salomon G, Saul J, Prues S, et al. Antimicrobial lubricant reduces rectal bacteria at transrectal prostate biopsy: results from a prospective randomized trial. World J Urol 2018;36:871-6.

45. Taher Y, et al. Prospective randomized controlled study to assess the effect of perineal region cleansing with povidone iodine before transrectal needle biopsy of the prostate on infectious complications. Urology 2014;84:S306

46. Gurbuz C, Canat L, Atis G, Caskurlu T. Reducing infectious complications after transrectal prostate needle biopsy using a disposable needle guide: is it possible? Int Braz J Urol 2011;37:79-84; discussion 85-6.

47. Tuncel A, et al. Does disposable needle guide minimize infectious complications after transrectal prostate needle biopsy? Urology 2008;71:1024-7; discussion 1027-8.

48. Tas M, et al. Comparison of patient comfort and complications of transrectal ultrasonography guided prostate biopsies using 16 and 18 Gauge needles. Türk Üroloji Derneği 2005;31:119-22.

49. Ozcan S, Akif Diri M, Bagcioglu M, Karakan T, Aydın A. Complications and prostate cancer diagnosis rate of TRUS prostate biopsies using 16 and $18 \mathrm{G}$ needles by Clavien scoring. Urologia. In press. http://dx.doi.org/10.5301/uj.5000238

50. Koc G, et al. Does washing the biopsy needle with povidone-iodine have an effect on infection rates after transrectal prostate needle biopsy? Urol Int 2010;85:147-51. 


\section{Clear benefit to reduce infections:}

- Rectal preparation with povidone-iodine - Antibiotic prophylaxis

Potential benefit to reduce infections:

- Antibiotic combinations for prophylaxis

- Targeted antibiotic prophylaxis

- Transperineal biopsy

No impact on infections:

- Number of biopsy cores

- Use of periprostatic nerve block

- Type of antibiotic class for prophylaxis

- Rectal preparation by enema 
Table 1 - Overview on randomised controlled trials evaluating fosfomycin versus ciprofloxacin

\begin{tabular}{|c|c|c|c|c|c|c|c|}
\hline Author (year) & Study period & Country & $\begin{array}{l}\text { Patients randomised } \\
\text { (analysed) }\end{array}$ & Antibiotic prophylaxis & $\begin{array}{l}\text { Infectious outcomes } \\
\text { reported }\end{array}$ & Follow-up & Infectious complications \\
\hline Sen et al (2015) [16] & $\begin{array}{l}\text { May } 2014 \text { to May } \\
\text { (February?) } 2015\end{array}$ & Turkey & $\begin{array}{l}\text { ST: } n=150(150) \\
\text { FOS: } n=150(150)\end{array}$ & $\begin{array}{l}\text { ST: Ciprofloxacin } 500 \mathrm{mg} \text { as single } \\
\text { shot } 1 \text { h before biopsy } \\
\text { FOS: Fosfomycin } 3 \mathrm{~g} \text { per os the night } \\
\text { before biopsy }\end{array}$ & $\begin{array}{l}\text { Febrile }\left(>38^{\circ} \mathrm{C}\right) \text { and } \\
\text { afebrile UTI }\end{array}$ & $1 \mathrm{mo}$ & $\begin{array}{l}\text { ST: } n=18(9 \%) \text {; febrile UTI }(n=1) \text {, afebrile UTI }(n=2) \\
\text { FOS: } n=11(7 \%) \text {; febrile UTI }(n=2) \text {, afebrile UTI }(n=9)\end{array}$ \\
\hline Fahmy et al (2016) [20] & $\begin{array}{l}\text { February } 2012 \text { to June } \\
2015\end{array}$ & Egypt & $\begin{array}{l}\text { ST: } n=210(210) \\
\text { FOS: } n=202(202)\end{array}$ & $\begin{array}{l}\text { ST: Ciprofloxacin } 500 \mathrm{mg} \text { and } \\
\text { metronidazole } 500 \mathrm{mg} \text { for } 3 \mathrm{~d} \text { b.i.d. } \\
\text { starting at least } 1 \mathrm{~h} \text { before biopsy } \\
\text { FOS: Fosfomycin } 3 \mathrm{~g} \text { per os } 1-2 \mathrm{~h} \\
\text { before biopsy }\end{array}$ & $\begin{array}{l}\text { Febrile }\left(>38^{\circ} \mathrm{C}\right) \text { and } \\
\text { afebrile UTI }\end{array}$ & $4 \mathrm{wk}$ & $\begin{array}{l}\text { ST: } n=18(9 \%) ; \text { febrile UTI }(n=4) \text {, afebrile UTI }(n=14) \\
\text { FOS: } n=4(2 \%) \text {; febrile UTI }(n=1) \text {, afebrile UTI }(n=3)\end{array}$ \\
\hline Lista et al (2014) [15] & $\begin{array}{l}\text { September } 2009 \text { to } \\
\text { December } 2010\end{array}$ & Spain & $\begin{array}{l}\text { ST: } n=312(312) \\
\text { FOS: } n=359(359)\end{array}$ & $\begin{array}{l}\text { ST: Ciprofloxacin } 500 \mathrm{mg} \text { for } 5 \mathrm{~d} \text { b.i.d., } \\
\text { starting point not specified } \\
\text { FOS: Fosfomycin } 3 \mathrm{~g} \text { per os } 24 \mathrm{~h} \\
\text { before and } 24 \mathrm{~h} \text { after biopsy }\end{array}$ & Fever $\left(>38^{\circ} \mathrm{C}\right)$ & $3 \mathrm{mo}$ & $\begin{array}{l}\text { ST: } n=7(2 \%) \\
\text { FOS: } n=9(3 \%)\end{array}$ \\
\hline
\end{tabular}

b.i.d. = bis in die (twice a day); FOS = fosfomycin group; ST = standard prophylaxis group (ciprofloxacin)1; UTI = urinary tract infection. 


\section{Table 2 - Overview on recent randomised controlled trials evaluating targeted antibiotic prophylaxis}

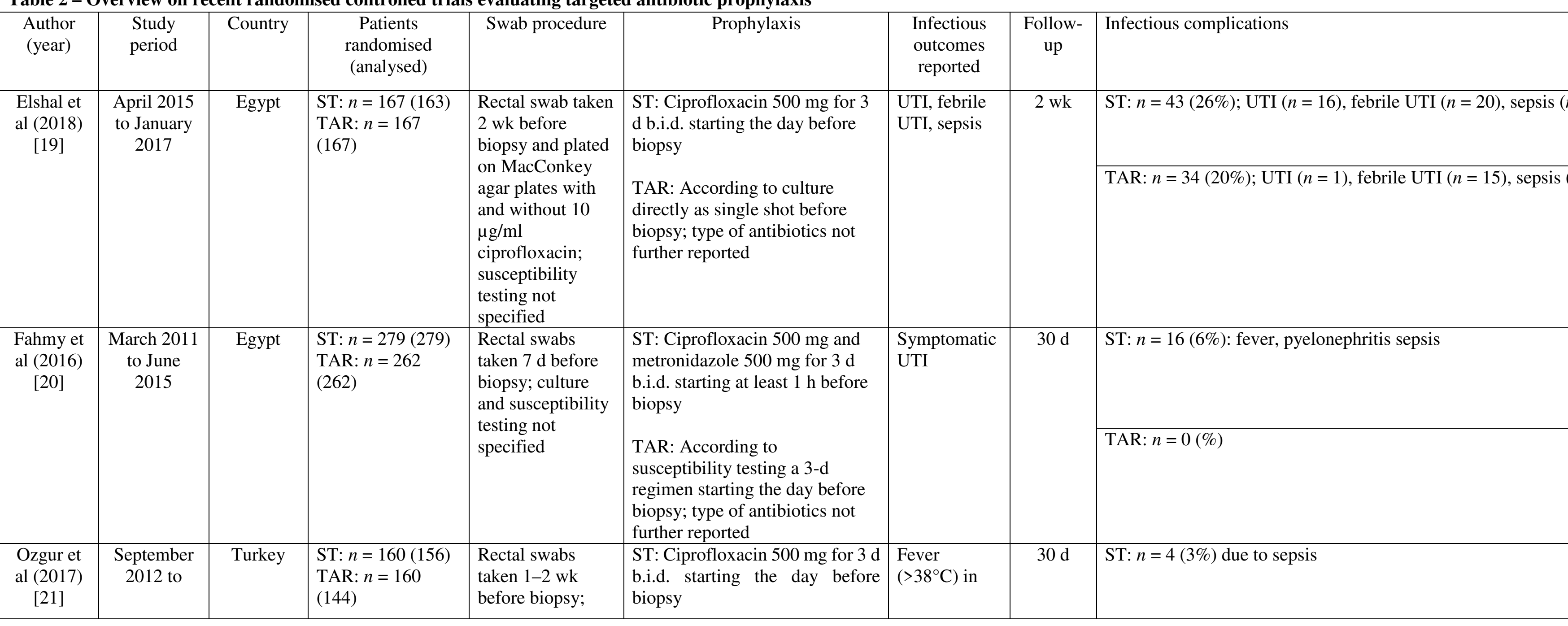




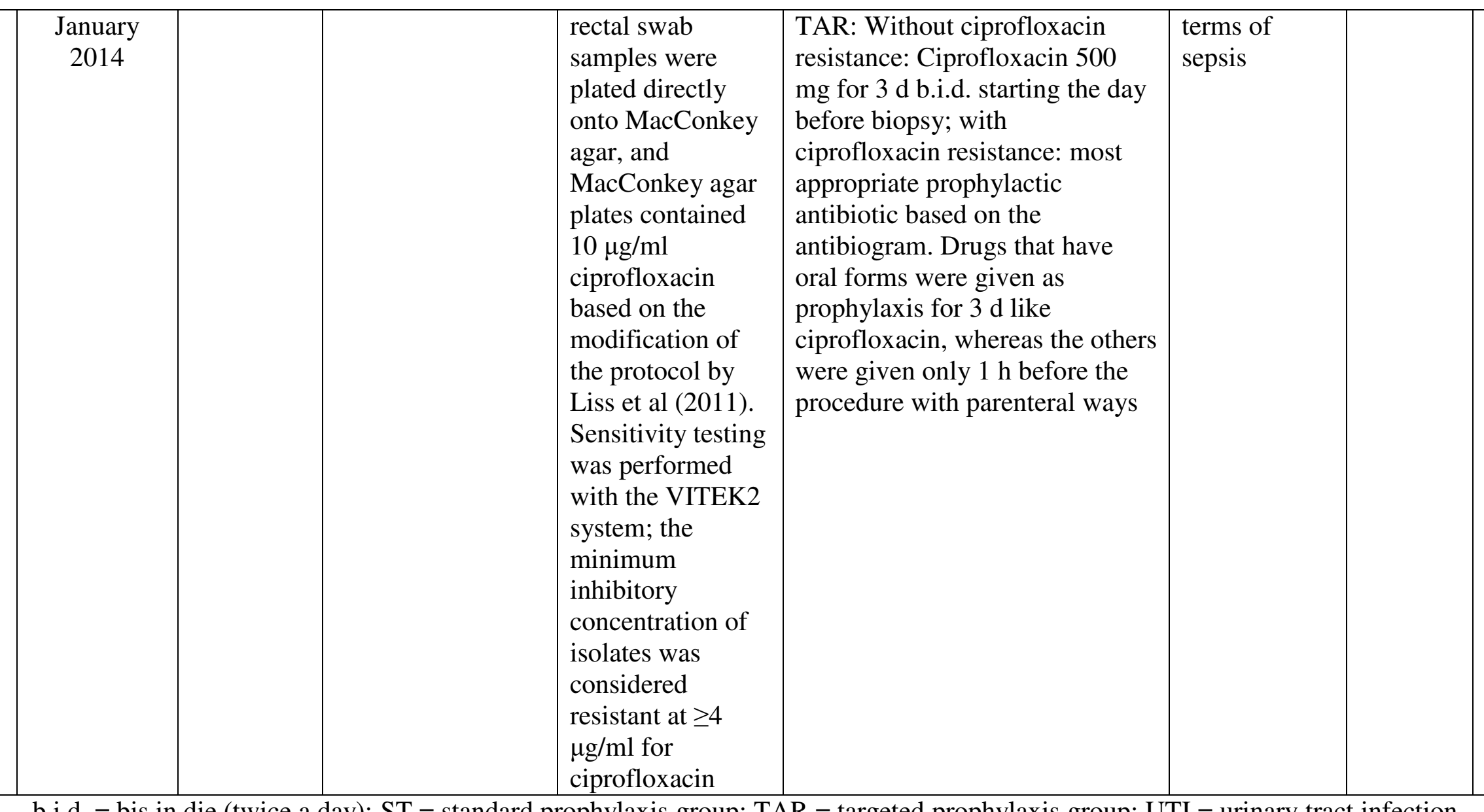

b.i.d. = bis in die (twice a day); ST = standard prophylaxis group; TAR = targeted prophylaxis group; UTI = urinary tract infection. 
Table 3 - Overview on randomised controlled trials evaluating number of biopsy cores and reporting infectious complications

\begin{tabular}{|c|c|c|c|c|c|c|c|c|}
\hline Author (year) & Study period & Country & $\begin{array}{l}\text { Patients } \\
\text { randomised } \\
\text { (analysed) }\end{array}$ & $\begin{array}{l}\text { Number of } \\
\text { cores }\end{array}$ & Antibiotic prophylaxis & $\begin{array}{l}\text { Infectious outcomes } \\
\text { reported }\end{array}$ & Follow-up & $\begin{array}{l}\text { Infectious } \\
\text { complications }\end{array}$ \\
\hline $\begin{array}{l}\text { Emiliozzi et al (2004) } \\
\text { [23] }\end{array}$ & $\begin{array}{l}\text { February } 2001 \text { to } \\
\text { December } 2002\end{array}$ & Italy & $\begin{array}{l}\text { ST: } n=107(107) \\
\text { EXT: } n=107 \\
(107)\end{array}$ & $\begin{array}{l}\text { ST: } n=6 \\
\text { EXT: } n=12\end{array}$ & Oral quinolones for $3 \mathrm{~d}$ & Fever & Unclear & $\begin{array}{l}\text { ST: } n=0(0 \%) \\
\text { EXT: } n=0(0 \%)\end{array}$ \\
\hline Irani et al (2013) [24] & $\begin{array}{l}\text { December } 2009 \text { to } \\
\text { November } 2011\end{array}$ & France & $\begin{array}{l}\text { ST: } n=170(158) \\
\text { EXT: } n=169 \\
(148)\end{array}$ & $\begin{array}{l}\text { ST: } n=12 \\
\text { EXT: } n=20\end{array}$ & $\begin{array}{l}\text { Patients received "systemic } \\
\text { antibiotic prophylaxis," but } \\
\text { not further specified }\end{array}$ & Fever, prostatitis & $15 \mathrm{~d}$ & $\begin{array}{l}\text { ST: } n=6(4 \%) ; \\
\text { fever }(n=3), \\
\text { prostatitis }(n=3) \\
\text { EXT: } n=3(2 \%) ; \\
\text { fever }(n=2), \\
\text { prostatitis }(n=1)\end{array}$ \\
\hline $\begin{array}{l}\text { Mariappan et al } \\
\text { (2004) [25] }\end{array}$ & $\begin{array}{l}\text { April } 2001 \text { to } \\
\text { March } 2003\end{array}$ & Malaysia & $\begin{array}{l}\text { ST: } n=69(69) \\
\text { EXT: } n=63(63)\end{array}$ & $\begin{array}{l}\text { ST: } n=6 \\
\text { EXT: } n=>6\end{array}$ & $\begin{array}{l}\text { Third-generation } \\
\text { cephalosporines or } \\
\text { quinolones, but not further } \\
\text { specified }\end{array}$ & Fever $>37.5^{\circ} \mathrm{C}$ & $3 \mathrm{wk}$ & $\begin{array}{l}\text { ST: } n=1(1 \%) \\
\text { EXT: } n=1(2 \%)\end{array}$ \\
\hline $\begin{array}{l}\text { Naughton et al (2000) } \\
{[26]}\end{array}$ & Not reported & USA & $\begin{array}{l}\text { ST: } n=72(72) \\
\text { EXT: } n=62(62)\end{array}$ & $\begin{array}{l}\text { ST: } n=6 \\
\text { EXT: } n=12\end{array}$ & $\begin{array}{l}\text { 3- to 5-d course of } \\
\text { quinolone starting the night } \\
\text { before biopsy }\end{array}$ & Fever & $4 \mathrm{wk}$ & $\begin{array}{l}\text { ST: } n=4(6 \%) \\
\text { EXT: } n=0(0 \%)\end{array}$ \\
\hline Paul et al (2004) [27] & $\begin{array}{l}\text { May } 2000 \text { to April } \\
2001\end{array}$ & Germany & $\begin{array}{l}\text { ST: } n=100(84) \\
\text { EXT: } n=100(88)\end{array}$ & $\begin{array}{l}\text { ST: } n=6 \\
\text { EXT: } n=10\end{array}$ & $\begin{array}{l}\text { Ciprofloxacin } 500 \mathrm{mg} / \mathrm{d} \\
\text { starting the evening before } \\
\text { biopsy for a total of } 5 \mathrm{~d}\end{array}$ & Fever $>38.8^{\circ} \mathrm{C}$ & $4 \mathrm{wk}$ & $\begin{array}{l}\text { ST: } n=2(2 \%) \\
\text { EXT: } n=2(2 \%)\end{array}$ \\
\hline
\end{tabular}




\begin{tabular}{|c|c|c|c|c|c|c|c|c|}
\hline $\begin{array}{l}\text { Rodríguez- } \\
\text { Covarrubias et al } \\
\text { (2011) [28] }\end{array}$ & $\begin{array}{l}\text { January } 2009 \text { to } \\
\text { January } 2010\end{array}$ & Mexico & $\begin{array}{l}\text { ST: } n=75(75) \\
\text { EXT: } n=75(75)\end{array}$ & $\begin{array}{l}\mathrm{ST}: n=12 \\
\mathrm{EXT}: n=18\end{array}$ & $\begin{array}{l}\text { Single shot of } \\
\text { piperacillin/tazobactam } \\
(4 / 0.5 \mathrm{~g}) \text { intravenously } 15 \\
\text { min before biopsy }\end{array}$ & Fever & $7 d$ & $\begin{array}{l}\mathrm{ST}: n=1(1 \%) \\
\mathrm{EXT}: n=1(1 \%)\end{array}$ \\
\hline Sur et al (2004) [29] & $\begin{array}{l}\text { February } 2000 \text { to } \\
\text { July } 2001\end{array}$ & USA & $\begin{array}{l}\text { ST: } n=88(88) \\
\text { EXT: } n=94(94)\end{array}$ & $\begin{array}{l}\text { ST: } n=6- \\
12 \\
\text { EXT: } n=24\end{array}$ & $\begin{array}{l}\text { Oral quinolones for } 3 \mathrm{~d} \\
\text { starting the day before } \\
\text { biopsy }\end{array}$ & Prostatitis, sepsis & $2 \mathrm{wk}$ & $\begin{array}{l}\text { ST: } n=0(0 \%) \\
\text { EXT: } n=0(0 \%)\end{array}$ \\
\hline
\end{tabular}

EXT $=$ extended number of biopsy cores; ST = standard number of biopsy cores. 
Table 4 - Overview on randomised controlled trials comparing transrectal versus transperineal biopsy

\begin{tabular}{|c|c|c|c|c|c|c|c|c|}
\hline Author (year) & Study period & Country & $\begin{array}{l}\text { Patients } \\
\text { randomised } \\
\text { (analysed) }\end{array}$ & $\begin{array}{l}\text { Number of } \\
\text { cores }\end{array}$ & $\begin{array}{l}\text { Antibiotic } \\
\text { prophylaxis }\end{array}$ & \begin{tabular}{|l|} 
Infectious \\
outcomes \\
reported
\end{tabular} & $\begin{array}{l}\text { Follow- } \\
\text { up }\end{array}$ & Infectious complications \\
\hline $\begin{array}{l}\text { Chae et al (2009) } \\
\text { [31] }\end{array}$ & $\begin{array}{l}\text { March } 2006 \text { to } \\
\text { December } 2007\end{array}$ & Korea & $\begin{array}{l}\text { TR: } n=100(100) \\
\text { TP: } n=100(100)\end{array}$ & $n=12$ & \begin{tabular}{|l|} 
Cephalosporine \\
plus \\
aminoglycoside \\
plus \\
metronidazole \\
intravenously \\
starting $1 \mathrm{~h}$ \\
before biopsy for \\
$1 \mathrm{~d}$ followed by a \\
3-d course of \\
quinolones. \\
\end{tabular} & Sepsis & $7 \mathrm{~d}$ & $\begin{array}{l}\text { TR: } n=1(1 \%) \\
\text { TP: } n=1(1 \%)\end{array}$ \\
\hline $\begin{array}{l}\text { Hara et al (2008) } \\
\text { [32] }\end{array}$ & $\begin{array}{l}\text { May } 2003 \text { to } \\
\text { October } 2005\end{array}$ & Japan & $\begin{array}{l}\text { TR: } n=120(120) \\
\text { TP: } n=126(126)\end{array}$ & $n=12$ & $\begin{array}{l}\text { Levofloxacin } 200 \\
\text { mg orally on the } \\
\text { day of biopsy, } \\
\text { but not further } \\
\text { specified }\end{array}$ & $\begin{array}{l}\text { Fever }>38.5^{\circ} \mathrm{C} \\
\text { prostatitis, sepsis }\end{array}$ & $2 \mathrm{wk}$ & $\begin{array}{l}\text { TR: } n=2(2 \%) ; \text { fever }(n=2), \text { sepsis }(n=0 \\
\text { TP: } n=0(0 \%)\end{array}$ \\
\hline $\begin{array}{l}\text { Takenaka et al } \\
\text { (2008) [33] }\end{array}$ & $\begin{array}{l}\text { May } 2003 \text { to } \\
\text { September } \\
2004\end{array}$ & Japan & $\begin{array}{l}\text { TR: } n=100(100) \\
\text { TP: } n=100(100)\end{array}$ & $n=12$ & $\begin{array}{l}\text { Levofloxacin } 300 \\
\text { mg orally for } 1 \mathrm{~d}, \\
\text { but not further } \\
\text { specified }\end{array}$ & Fever $>38.5^{\circ} \mathrm{C}$ & $4 \mathrm{wk}$ & $\begin{array}{l}\text { TR: } n=2(2 \%) \\
\text { TP: } n=1(1 \%)\end{array}$ \\
\hline
\end{tabular}

$\mathrm{TP}=$ transperineal biopsy; $\mathrm{TR}=$ transrectal biopsy. 